\title{
Research on the Application of Action - oriented Teaching Method in Business Oral English Teaching
}

\author{
Kou Junjia \\ Jiangxi Teachers College, Yingtan, Jiangxi, 335000, China
}

\section{Keywords: Action-oriented; teaching method; business oral English teaching}

\begin{abstract}
Cultivating the key ability is as the core of the business oral English teaching, and the action-oriented teaching method with the student-center has very important practical significance in the development of higher vocational education. In addition, the new and practical concept of the vocational education is highly recognized by the domestic and international vocational education, which attracts more and more attention. In the teaching method of business oral English teaching, the action-oriented teaching method have played a positive guiding role to cultivate the practical use of business talent. In this paper, we show the research on the application of the action-oriented teaching method in business oral English teaching.
\end{abstract}

\section{Introduction}

With the deepening of the reform and the rapid development of the economy, China's economic status has shown the advantages of continuous progress in the development of the world [1]. Altrough different countries around the world are between the opportunities and projects of cooperation between enterprises, their economies are also greatly increased. The completion of these collaborative projects involves the participation of people with the considerable business English knowledge and skills, thus the business oral English teaching occupies a very important position to meet the needs of the market competition. In addition, more and more higher and professional vocational colleges will improve the students' oral proficiency and practical application ability with the improvement of training and teaching skills [2]. In the focus of reform, the business English major of the institution has set the "Business Oral English " course as a professional and core course. However, there are many problems in the oral English teaching of our country at present. For example, many students reflect that the oral class is a little boring, and some teachers are simply speaking and training in the classroom, however students have the opportunity to speak in the spoken language class, and there is such a situation even outside the classroom [3][4]. This makes the students' oral communication ability stagnant, and they have the low learning interest and low passion to paticipate in the class. Therefore, it is necessary to change the traditional oral English teaching method. In addition, the business oral English teaching has been engaged in business English for many years, and we have been exploring how to improve the oral teaching method. We find that the action-oriented teaching method is very important for the practice of the business oral English teaching, which can effect the students interesting of the business oral English.

\section{Action-oriented teaching method}

Action-oriented teaching method is a typical student-centered teaching method, in which students deal with the whole process of a project under the guidance of teachers in person, and they can master the teaching plan within the teaching content in the process of learning. All or part of students arrange the learning behavior to solve the difficulties, which are encountered in dealing with the project [5]. The action-oriented teaching method can improve the interest of students, and it is naturally able to mobilize the enthusiasm of learning. In July 2016, German Federal Vocational Education Institute developed the action-oriented project teaching method. The action-oriented teaching method has several characteristics. Firstly, the entire learning process is included into a specific project or event, and the teacher should design a project teaching program according to the action loop design teaching ideas, which can impart the knowledge to students and operational skills. 
More importantly, the action-oriented teaching method can develop students`s professional ability and the ability to solve the problem. Finally, the most significant feature is the "Project is as the main line, while teachers for the guidance of students is as the key", changed the past." Teachers say that the passive teaching mode can inspire students to take the initiative to participate in self-cooperation, and to explore innovative new teaching mode [6]. In addition, students are seen as the main body of learning. With the independent completion of the project, the theory and practice are combined. Thus the action-oriented teaching method can not only improve the theoretical level and practical skills, but also solve the problem and other comprehensive ability under the guidance of teachers and the guidance of training. It can be said that the project teaching method is to complete the project with a teacher and students as the common progress of teaching methods. As shown in Figure 1, there are six critical questions things to think about when someone has something to say in the business oral English teaching.

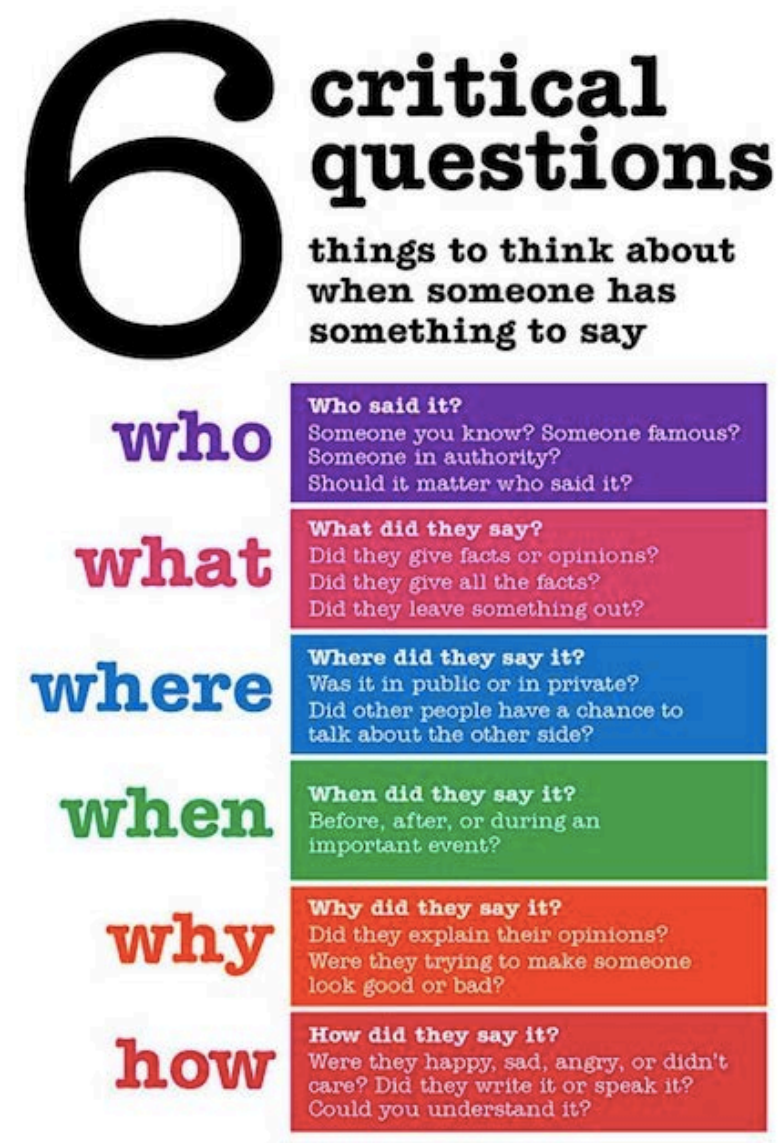

Figure 1. Six critical questions things to think about when someone has something to say in the business oral English teaching.

\section{The application of action-oriented teaching in business oral English teaching}

Business oral English teaching requires that teachers should teach the relevant business English professional knowledge in the classroom, and students should speak their oral and practical skills with the professional and practical characteristics. How can I get better on this course? I think there is a good effect of using the action-oriented teaching [7]. The teaching materials currently used by our institute are edited by Liu Jieying and published by Dalian University of Technology Press. Each book contains 12 units which includes four sections: Warmingup, Situationaldialogues, Practice and Learning more. In this study, two of them were selected to analyze the application of action-oriented teaching method in business oral English class. The basic method of the action-oriented teaching is that the classroom tasks give the introductory and goal requirements, and the students perform the tasks of the tour and guidance with the task after the end of the comments and scoring. In the textbook unit 1 Job Hunting, there is a scenario in the career counseling center, which is about that job seekers want to get the help of the professional counseling room after graduating from the university campus. 
Thus it designed a lot of professional expressions, commonly used sentences and related attention Such as instrumentation. Students play the role, in which one is the job seeker and the other is the consultant [8]. If the content of the understanding is not comprehensive enough in the view of the students, teachers can give some guidance, such as given some reference points, as shown in the following Table 1.

Table 1. Tips for the Career Advisor to Know the Graduates

\begin{tabular}{c|c|c|c}
\hline Index & Content & Index & Content \\
\hline 1 & Personal data & 7 & $\begin{array}{c}\text { Comprehensive } \\
\text { abilities }\end{array}$ \\
\hline 2 & Major & 8 & $\begin{array}{c}\text { Hobbies and } \\
\text { interests }\end{array}$ \\
\hline 4 & $\begin{array}{c}\text { Performance in } \\
\text { college }\end{array}$ & 10 & $\begin{array}{c}\text { Strengths of } \\
\text { character }\end{array}$ \\
\hline 5 & $\begin{array}{c}\text { Foreign } \\
\text { languages } \\
\text { proficiency }\end{array}$ & 11 & $\begin{array}{c}\text { Job experiences } \\
\text { chancter }\end{array}$ \\
\hline 6 & $\begin{array}{c}\text { Honors and } \\
\text { accomplishments }\end{array}$ & 12 & $\begin{array}{c}\text { Attitude towards } \\
\text { the new job }\end{array}$ \\
\hline
\end{tabular}

In this process, students are emotionally elevated, and they are fully involved in the discussion. After the end of a role play they will exchange the identities again. After about 20-30 minutes, the teacher can ask them to stop the discussion and ask whether the students are willing to take the initiative to show up for everyone. In the author's class, very few students will be asked to answer questions [2]. I will always use the incentive method to allow students to take the initiative to show up, because the Chinese students are not as we imagined for the introverted performance, which turns out that most students in this situation will be enthusiastic up and down. After the students every time after the performance of the teacher to comment, or praise or encouragement, good drive poor, and actively lead the introversion, oral classroom effect is very good. As shown in Figure 2, the business scene reproduction in business oral English teaching is given.

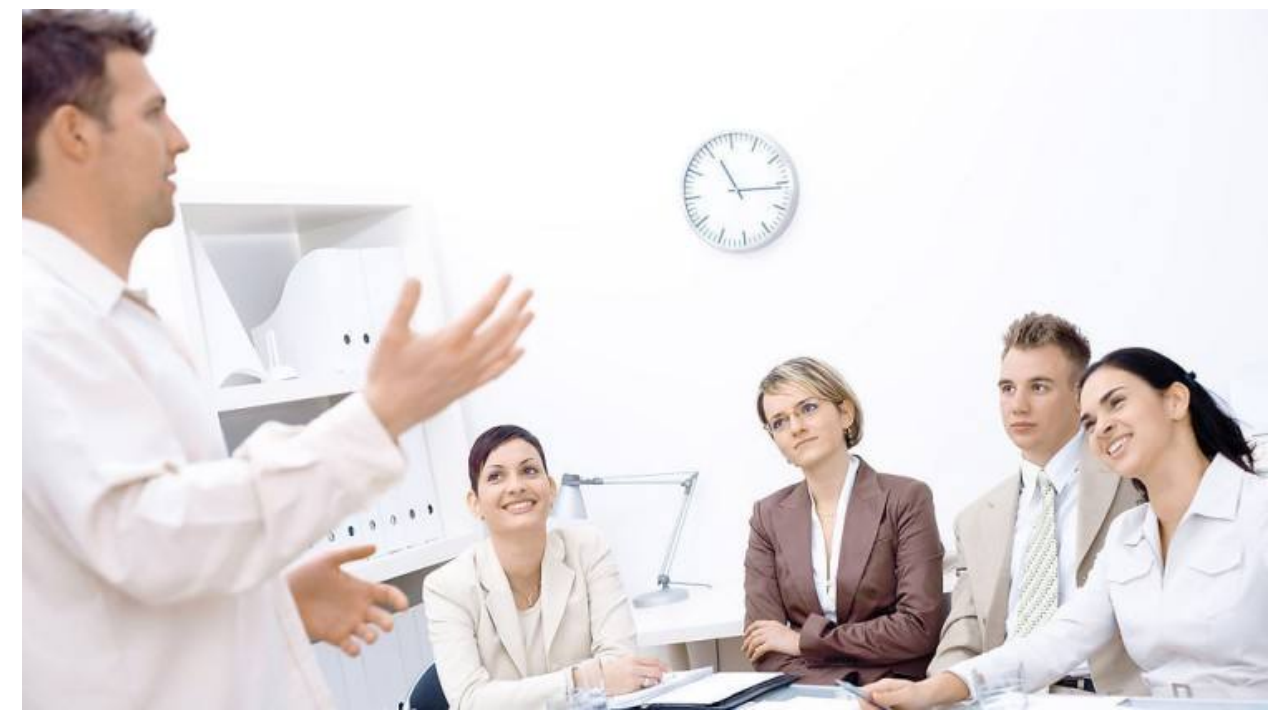

Figure 2. A Business Scene Reproduction in Business English Oral English Teaching

There is a scene in the other unit, a meeting at the airport and on the taxi ride to the hotel have a small talk with the guest, which gives him a brief introduction of the city and introduces the scenic places and buildings along the street with the author inspiration. Then let them play a role of foreign customers and a local company employees to introduce the famous attractions and food. As most of the students are more familiar with the city, so their role play is very good and they are happy to introduce the "Yangcheng eight", "Xiguan food" and some other characteristics of Guangzhou 
tourism culture, which has a strong practical [4]. Students can learned a lot of words and expressions that they did not know before. Then I come to the campus and you introduce our school to your friends and talk about your college life with him / her. I would like to talk about your college life with him / her. The power and passion of the students' speeches are rekindled, and they are free to group play and dialogue. This kind of oral practice is different from reading the textbook dialogue, and the spontaneous organization of language and instant expressions are very popular with students because of the real situation and in line with their real life. In addition, the action-oriented teaching method can overcome the Chinese characteristics of college students oral college students. Too many people can not take into account the shortcomings of each student, which will be put into the role of dialogue. Of course, each classroom will have several introverted students, who are not willing to take the initiative into the practice [6]. At that time, the teacher should play a supervisory role, and can give them with some active partner, and then this problem will be solved. In the final live demonstration session, many students are very active from the classroom door to the middle of the classroom, while they can walk around the scenery as if a tour guide in the side of their friends to introduce the same side of the scenery. In this action-oriented teaching method, students can learn from practice in theory through personal experience. This theory is connected with the actual, while the traditional purely taught and dialogue practice effect is obvious boring.

\subsection{Action-oriented teaching method in the classroom}

In the business English oral teaching classroom, the action-oriented teaching method has played a very important role. Classroom dialogue, questions and answers, the role of the play and the final voluntary display are with students as the main body in the classroom activities at the same time, and fully exercise the students' spoken language can improve the practical oral application ability [8]. Teachers in the whole process only give the task to guide students from the performance of the study and the performance of the students give guidance, comments and praise to encourage. And this classroom model can avoid the traditional teacher-based lectures, students, supplemented by the drawbacks of class. Meanwhile it can avoid the general oral classroom repetitive practice exercises monotonous, so that students are tired and even lose the interest of learning to speak. As shown in Figure 3, the action-oriented teaching method to practice brush words is shown.

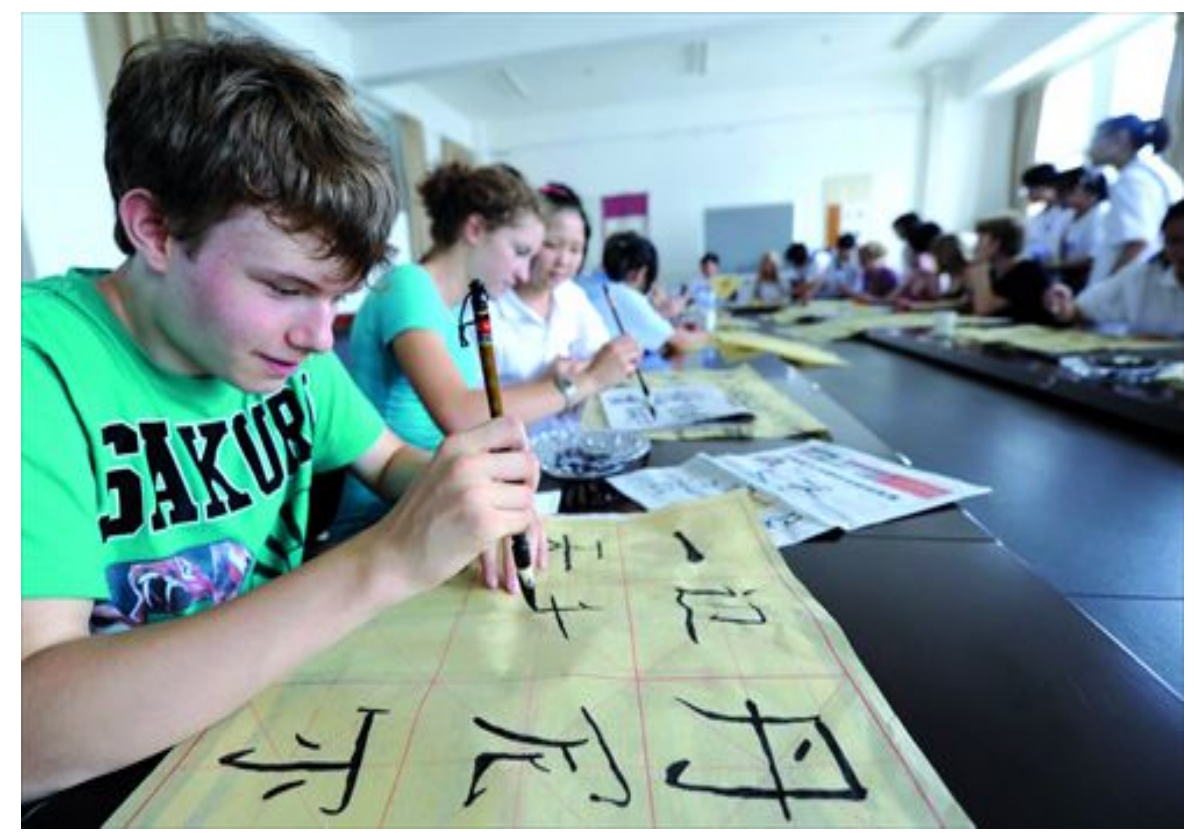

Figure 3. Example of the action-oriented teaching method to practice brush words

\subsection{The dialectical application of action-oriented teaching method}

In the action-oriented teaching method, the teachers are not to become the classroom bystanders, who did not take enough responsibility. I would like to clarify that the teacher's burden is not only not 
easy but more challenging with the use of action-oriented teaching method. The teacher in the class need to think about the appropriate role-playing scenarios, and consider the difficult topic, and prepare the appropriate group and then Discuss the topic, etc., which spend more time and calls more energy even more than the traditional classroom lesson. In addition, the action-oriented teaching classroom requires teachers to have the sufficient control, and to cope with possible emergencies. And the teachers also prepare a second program to deal with that the current program can not be proceed smoothly. Secondly, the author uses the action-oriented teaching method to have a reasonable schedule. In the business oral English teaching, each teacher teaches two classes based on the basic knowledge of oral learning. Once the students have finished learning the contents of a lesson just after the fatigue of the psychological, the second section of the author should be learned with use of action-oriented teaching method. With the theory and practice, students will not learn tired, teacher teaching will not suffer.

\section{Summary}

From the above example, we can see that the action-oriented teaching method is actually a behavioral teaching model in the project teaching, in which the learning process becomes a participant in the creation of practical activities. And students in the project practice process should understand and grasp the knowledge and skills required by the course, experience the hardships and pleasures of innovation, and cultivate ideas and methods of analyzing problems to solve problems. The application of action-oriented pedagogy in business oral English teaching also makes the subject play its proper teaching effect, exercise the students 'oral expression ability and improve the students' interest in learning spoken language.

\section{References}

[1] Barrett N E, Liu G Z. Global Trends and Research Aims for English Academic Oral Presentations: Changes, Challenges, and Opportunities for Learning Technology[J]. Review of Educational Research, 2016, 86(4): 1227-1271.

[2] Feldman A. An Emergent History of Educational Action Research in the English-Speaking World[M]//The Palgrave International Handbook of Action Research. Palgrave Macmillan US, 2017: 125-145.

[3] Aloreibi A, Carey M D. English Language Teaching in Libya After Gaddafi[M]//English Language Education Policy in the Middle East and North Africa. Springer International Publishing, 2017: 93-114.

[4] Perkins D D, Fisher B W, Karakos H L, et al. Thinking and Acting both Globally and Locally: The Field School in Intercultural Education as a Model for Action-Research Training and Civic Learning[J]. Collaborations: A Journal of Community-Based Research and Practice, 2017, 1(1): 3.

[5] Ai B, Wang L. Re-entering my space: a narrative inquiry into teaching English as a foreign language in an imagined third space[J]. Teachers and Teaching, 2017, 23(2): 227-240.

[6] Burns A, McPherson P. Action Research as Iterative Design: Implications for English Language Education Research[M]//Reflections on Qualitative Research in Language and Literacy Education. Springer International Publishing, 2017: 105-120.

[7] Jo H M. Middle school English teachers' knowledge and practice on pragmatics in South Korea: An exploratory sequential mixed methods study[D]. Northern Arizona University, 2016.

[8] Hsu W. Harvard Business School (HBS) Case Method to Teaching English for Business Communication[J]. Education and Linguistics Research, 2016, 2(2): 95. 